\title{
WATER, ENERGY, AND BIOGEOCHEMICAL BUDGET RESEARCH AT SLEEPERS RIVER RESEARCH WATERSHED, VERMONT
}

By James B. Shanley, Eric T. Sundquist, and Carol Kendall

U.S. GEOLOGICAL SURVEY

Open-File Report 94-475

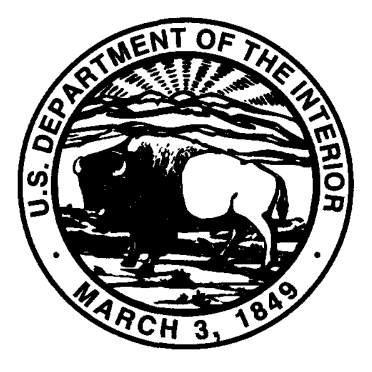

Bow, New Hampshire 1995 


\title{
DEPARTMENT OF THE INTERIOR BRUCE BABBITT, Secretary
}

\author{
U.S. GEOLOGICAL SURVEY \\ Gordon P. Eaton, Director
}

For additional information write to:

District Chief,

New Hampshire-Vermont District

U.S. Geological Survey

Water Resources Division

525 Clinton St.

Bow, $\mathrm{NH} 03304$
Copies of this report can be purchased from:

U.S. Geological Survey

Earth Science Information Center

Open-File Reports Section

Box 25286, MS 517

Denver Federal Center

Denver, CO 80225 


\section{CONTENTS}

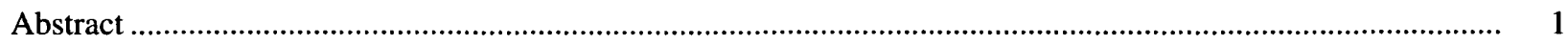

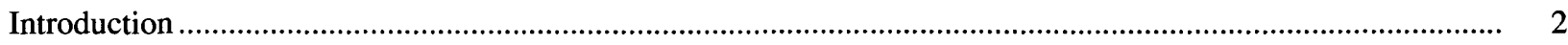

Background on Sleepers River Research Watershed ........................................................................................ 2

Description of Sleepers River Research Watershed...................................................................................... 3

Historical Data-Collection and Research Activities .............................................................................. $\quad 5$

Current Data-Collection Activities ........................................................................................................... 5

Water, Energy, and Biogeochemical Budgets Research Activities at Sleepers River Research Watershed ............ 7

Research Elements ........................................................................................................................... 7

I_Hillslope Hydrochemistry ................................................................................................... 7

II-Flowpath Delineation ........................................................................................................ 10

III-Effects of Seasonal Freezing and Snowpack on Soil Trace-Gas Budgets ................................ 13

IV - Hydrologic Processes at Different Scales ..................................................................... 16

V-Energy Processes in a Northern Temperate Climate............................................................. 17

Supporting Laboratory Facilities...................................................................................................... 19

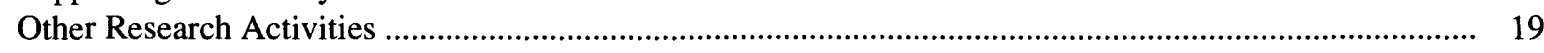

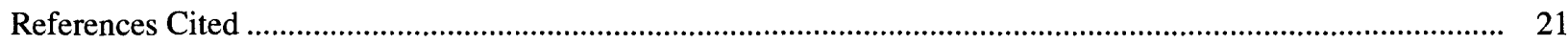

\section{FIGURES}

1,2. Maps showing:

1. Location of streamflow-gaging stations and meteorological stations in Sleepers

River Research Watershed, Vermont....

2. Hillslope hydrology research plot, Vermont .................................................................................. 9

\section{TABLES}

1. Drainage areas and periods of discharge records for subwatersheds of the Sleepers River

Research Watershed, Vermont

2. Summary of meteorological data available at Sleepers River Research Watershed, Vermont

3. Summary of measurements and instrumentation for Sleepers River Research

Watershed, Vermont 


\begin{tabular}{|c|c|c|}
\hline Multiply & By & To obtain \\
\hline \multicolumn{3}{|c|}{ Length } \\
\hline centimeter $(\mathrm{cm})$ & 0.394 & inch (in.) \\
\hline meter $(\mathrm{m})$ & 3.28 & foot $(\mathrm{ft})$ \\
\hline kilometer $(\mathrm{km})$ & 0.6215 & mile (mi) \\
\hline \multicolumn{3}{|c|}{ Area } \\
\hline \multirow[t]{3}{*}{ square kilometer $\left(\mathrm{km}^{2}\right)$} & 0.386 & square mile $\left(\mathrm{mi}^{2}\right)$ \\
\hline & 00 & hectare (ha) \\
\hline \multirow{2}{*}{\multicolumn{3}{|c|}{ Temperature is given in degrees Celsius $\left({ }^{\circ} \mathrm{C}\right)$, which can be converted to degrees Fahrenheit $\left({ }^{\circ} \mathrm{F}\right)$}} \\
\hline & & \\
\hline \multicolumn{3}{|c|}{ by use of the following equation: } \\
\hline \multicolumn{3}{|c|}{${ }^{\circ} \mathrm{F}=1.8\left({ }^{\circ} \mathrm{C}\right)+32$} \\
\hline
\end{tabular}

Vertical datum: In this report "sea level" refers to the National Geodetic Vertical Datum of 1929_a geodetic datum derived from a general adjustment of the first-order level nets of the United States and Canada, formerly called Sea Level Datum of 1929.

\section{Abbreviations used in this report:}

$\begin{array}{ll}\text { ANC } & \text { Acid-neutralizing capacity } \\ \text { ARS } & \text { Agricultural Research Service } \\ \text { CRREL } & \text { Cold Regions Research and Engineering Laboratory } \\ \text { DOC } & \text { Dissolved organic carbon } \\ \text { GIS } & \text { Geographic Information System } \\ \text { NAWQA } & \text { National Water Quality Assessment } \\ \text { NWS } & \text { National Weather Service } \\ \text { SUNY } & \text { State University of New York } \\ \text { TDR } & \text { Time-domain reflectometry } \\ \text { USGS } & \text { U.S. Geological Survey } \\ \text { UVM } & \text { University of Vermont } \\ \text { WEBB } & \text { Water, Energy, and Biogeochemical Budgets } \\ \text { WMO } & \text { World Meteorological Organization }\end{array}$




\title{
WATER, ENERGY, AND BIOGEOCHEMICAL BUDGET RESEARCH AT SLEEPERS RIVER RESEARCH WATERSHED, VERMONT
}

\author{
By James B. Shanley, Eric T. Sundquist, and Carol Kendall
}

\section{Abstract}

The U.S. Geological Survey has selected the Sleepers River Research Watershed (Sleepers River) near Danville, Vt., as one of five sites for the investigation of Water, Energy, and Biogeochemical Budgets (WEBB). Sleepers River was chosen because it is a well-designed outdoor laboratory with a long history of hydrologic data collection and research, and also because it provides an ideal opportunity for collaboration among the U.S. Geological Survey, other Federal agencies, and universities. The subbasins at Sleepers River present a unique opportunity to investigate hydrologic, energy, and biogeochemical processes at a range of spatial scales. This WEBB study builds on fundamental research on process mechanisms and rates at the plot scale (in this case, a hillslope). Results then are scaled up to interpret the hydrochemical response of first- and higher-order basins. Five research elements make up the Sleepers River WEBB project. Individually, each of the five elements is designed to investigate specific WEBB processes (such as $\mathrm{CO}_{2}$ efflux through a snowpack), address specific WEBB issues (such as scaling and flow paths), or apply specific WEBB approaches (such as integrated chemical and physical study of a hillslope). Collectively, the five elements constitute a comprehensive investigation of WEBB processes needed to understand the possible effects of global change. The research elements overlap so that many of the processes investigated will be assessed in more than one way, thus allowing independent verification of research results. For example, flow-path information will be derived separately by use of isotopic tracers, conservative chemical solutes, and soil-moisture fluxes. The research elements also are closely integrated to take full advantage of this opportunity to coordinate interdisciplinary studies of water, energy, and biogeochemical budgets.

The WEBB project at Sleepers River consists of five integrated research elements; hillslope hydrochemistry, flow-path delineation, effect of seasonal freezing and snowpack on soil trace-gas fluxes, hydrologic processes at different scales, and energy processes in a northern temperate climate. Initially, the research will focus on a small forested headwater catchment. A headwater hillslope (from ridge to stream channel) has been extensively instrumented for the hillslope-hydrochemistry research element. Research at the hillslope will provide information directed toward an improved understanding of water and solute movement, including soil wetting and drying patterns, water flux through the soil column, saturated area dynamics and water-table fluctuations in the riparian zone, chemical evolution of soil water as it moves toward the stream, isotopic data that constrain the possible flow paths to the stream, and trace-gas fluxes from the soil. The intensive data from the hillslope plot will form the basis for the identification of the important hydrochemical processes in the basin. This core information then will be evaluated from the larger-scale perspective to determine the relative importance of hydrochemical processes in progressively larger basins.

The other four research elements are integrated with the hillslope hydrochemistry research. In the flow-path-delineation analysis, conservative isotopes such as oxygen-18 will be used in 
conjunction with conservative chemical tracers to identify hydrologic flow paths. Because each type of chemical and isotopic tracer provides different but complementary information, the several tracers that will be used at Sleepers River improve the potential success at flow-path delineation. In the trace-gas investigation, seasonal fluxes and concentrations of soil $\mathrm{CO}_{2}, \mathrm{~N}_{2} \mathrm{O}$, and $\mathrm{CH}_{4}$ will be measured in forested and agricultural settings. The measurements will be related to other experiments and models designed to determine which processes are the most important in controlling trace-gas budgets. In the hydrologic-scale research element, process research at the hillslope level will be applied to higher-order basins in two ways: by determining the relative partitioning of hydrologic pathways as basin scale increases and by assessing whether shifts in the partitioning are related to differences in basin physical factors. Finally, in the energy-processes investigation, the response of the soil thermal regime to incoming surface energy and geothermal flux will be investigated by simultaneous measurements of soil-temperature profiles and energy fluxes at several points in the basin.

\section{INTRODUCTION}

Understanding and predicting global change has become one of the major scientific focal points of the late 20th century. Concern over potential climatic change has mobilized scientists from many disciplines and nations around the world to improve the accuracy of climate-system modeling, and thereby improve the prediction of future climatic patterns. Since the early 1960 's, atmospheric scientists have made substantial progress in developing computer models that account for most of the important components of the climate system. Significant progress is needed, however, in areas such as cloud dynamics and processes associated with the exchanges of water, energy, and carbon between the land surface (including vegetation) and the atmosphere. Progress in this latter area requires the combined knowledge and skills of specialists in many fields, including the hydrologic, ecologic, geologic, geochemical, and atmospheric sciences.

To strengthen terrestrial-process research associated with the interactions of water, energy, gases, nutrients, and vegetation, the U.S. Geological Survey (USGS), as part of its Global Change Research
Program, initiated an intensive study of Water, Energy, and Biogeochemical Budgets (WEBB) in 1990. The purpose of WEBB is twofold. The first objective is to improve understanding of the processes controlling terrestrial water, energy, and biogeochemical fluxes, the interactions of these processes, and relations of these processes to climatic variables. The second objective is to improve the capability to predict continental water, energy, and biogeochemical budgets for a range of spatial and temporal scales.

WEBB process studies are being implemented as a systematic program of intensive, long-term field investigations. Study sites are selected on the basis of geographical and environmental diversity. Sites where data collection and (or) WEBB-related process investigations are already underway-especially such established multidisciplinary research locations as the LongTerm Ecological Research (LTER) sites sponsored by the National Research Foundation, the U.S. Forest Service Experimental Forests, UNESCO-designated International Biosphere Reserves, and other similar research sites-are given priority. A major emphasis of WEBB investigations is the development and maintenance of strong collaborative relationships with scientists in other Federal agencies and in the academic community.

This report describes the site characteristics, data collection, USGS research, and cooperative research activities at one such WEBB site, the Sleepers River Research Watershed near Danville, Vt. The status of ongoing and planned research in five interrelated research elements is given as of May 1994.

\section{BACKGROUND ON SLEEPERS RIVER RESEARCH WATERSHED}

In the late 1960 's, two researchers dug a trench at the base of a hillslope in northeastern Vermont to observe where, when, and how much of the snowmelt and rainfall (and water from sprinklers) that was applied to the hillslope reappeared at its base. Their work suggested that the delivery of subsurface water from the hillslope, even under wet antecedent conditions, was too delayed to have an appreciable effect on the event hydrograph of the stream at the base of the slope. They used these observations to refine the concept that runoff from saturated partial (variable) contributing areas dominates the event hydrograph in humid regions (Dunne and Black, 1970a,b; 1971). 
Since the time of the experiments of Dunne and Black, technical advances in data acquisition and instrumentation for the measurement of physical characteristics (soil moisture, temperature, ground frost penetration, ground-water levels) have provided new tools for reexamining these fundamental concepts of streamflow generation. By use of these newer techniques, as well as chemical and isotopic techniques for delineating flow paths, this study considers the processes that affect not only water transport but also solute chemistry, trace-gas budgets, and energy balance.

In the northern United States, WEBB processes are strongly controlled by spatial and temporal variations of snow cover, freezing, and melting. The pattern of snow accumulation and snowmelt - the dominant hydrologic feature of cold temperate regions-can be greatly altered by even small changes in incoming surface energy and geothermal flux. The pronounced seasonal pattern of runoff in northern forests, governed by seasonal snowpack development and ground-water recharge by snowmelt, may undergo dramatic shifts in response to climatic change. The potential for future summer drying in middle latitudes, suggested by some climate models, may be critically sensitive to interactions between soil water and energy balances during periods of snowmelt (Mitchell and Warrilow, 1987). Changes in runoff quantity and distribution would have important implications for overall water yield and water-supply management strategies and for solute transport.

WEBB studies at Sleepers River represent a unique opportunity to investigate how biogeochemical processes are affected by snow cover, freezing, and melting, and to use historical data to examine the relations between these processes and climatic variables. Integrated studies of biogeochemical processes (such as trace-gas fluxes and acid precipitation buffering) will elucidate the relations of these processes to the dynamic seasonal variations in water and energy fluxes. Thus, results of WEBB studies at Sleepers River are making fundamental contributions toward understanding potential future effects of changes in climate and land use on drainage basin processes that are affected by snow cover, freezing, and melting.

\section{Description of Sleepers River Research Watershed}

The Sleepers River Research Watershed of northeastern Vermont is a rural 43-mi ${ }^{2}$ subbasin of the Passumpsic River Basin, which is part of the Connecticut
River Basin (fig. 1). The rolling to mountainous Sleepers River drainage basin is 67 percent forested (conifers, hardwoods and mixtures of both); most of the remaining land is equally divided among pasture and hayland in support of dairy farming, the major agricultural industry. Less than 1 percent of the drainage-basin land area is planted in corn. There are no urban areas in the drainage basin.

The rolling topography at Sleepers River is typical of northern New England and northeastern New York. Elevations in the drainage basin range from 201 to $780 \mathrm{~m}$ above sea level. Bedrock is primarily the Waits River Formation, which is composed of calcareous granulite interbedded with quartz mica schist. From 1 to $20 \mathrm{~m}$ of calcareous till mantles the bedrock. The Sleepers River drainage basin contains no flood-control structures and only a few small ponds and bogs. The subbasins in Sleepers River Basin are circular or fan shaped and the stream channels are stable with almost no meandering. The subbasins with streamflow gages range in size from 0.47 to $112 \mathrm{~km}^{2}$.

The climate of the area is characterized by long, cold winters and cool summers. Air temperature ranges from about $-40^{\circ} \mathrm{C}$ to $37^{\circ} \mathrm{C}$ with a mean annual temperature of $6^{\circ} \mathrm{C}$. Mean temperature for June-September is $12^{\circ} \mathrm{C}$, and mean temperature for December-February is $-10^{\circ} \mathrm{C}$.

Average annual precipitation at Sleepers River ranges from $90 \mathrm{~cm}$ at low elevations to $125 \mathrm{~cm}$ at upper elevations; about 25 percent of this amount falls as snow. Snow generally covers the basin from early December to mid-April. Annual class-A pan evaporation ranges from an average of $71 \mathrm{~cm}$ at low elevations to $56 \mathrm{~cm}$ at upper elevations. Annual evapotranspiration at low elevations, based on water-balance calculations, is $51 \mathrm{~cm}$. Annual runoff averages about $30 \mathrm{~cm}$ at low elevations to $51 \mathrm{~cm}$ at upper elevations. Snowmelt usually produces the annual peak runoff event. Minimum flow normally occurs between July and October.

The State of Vermont owns tracts of land in the western upland areas, including the entire subbasin W-9. All other land at Sleepers River is privately owned, and all data-collection activities are subject to lease agreements. The history of cooperation between research staff and local landowners at Sleepers River has been strong as is borne out by the 35 years of research activity in the drainage basin. 


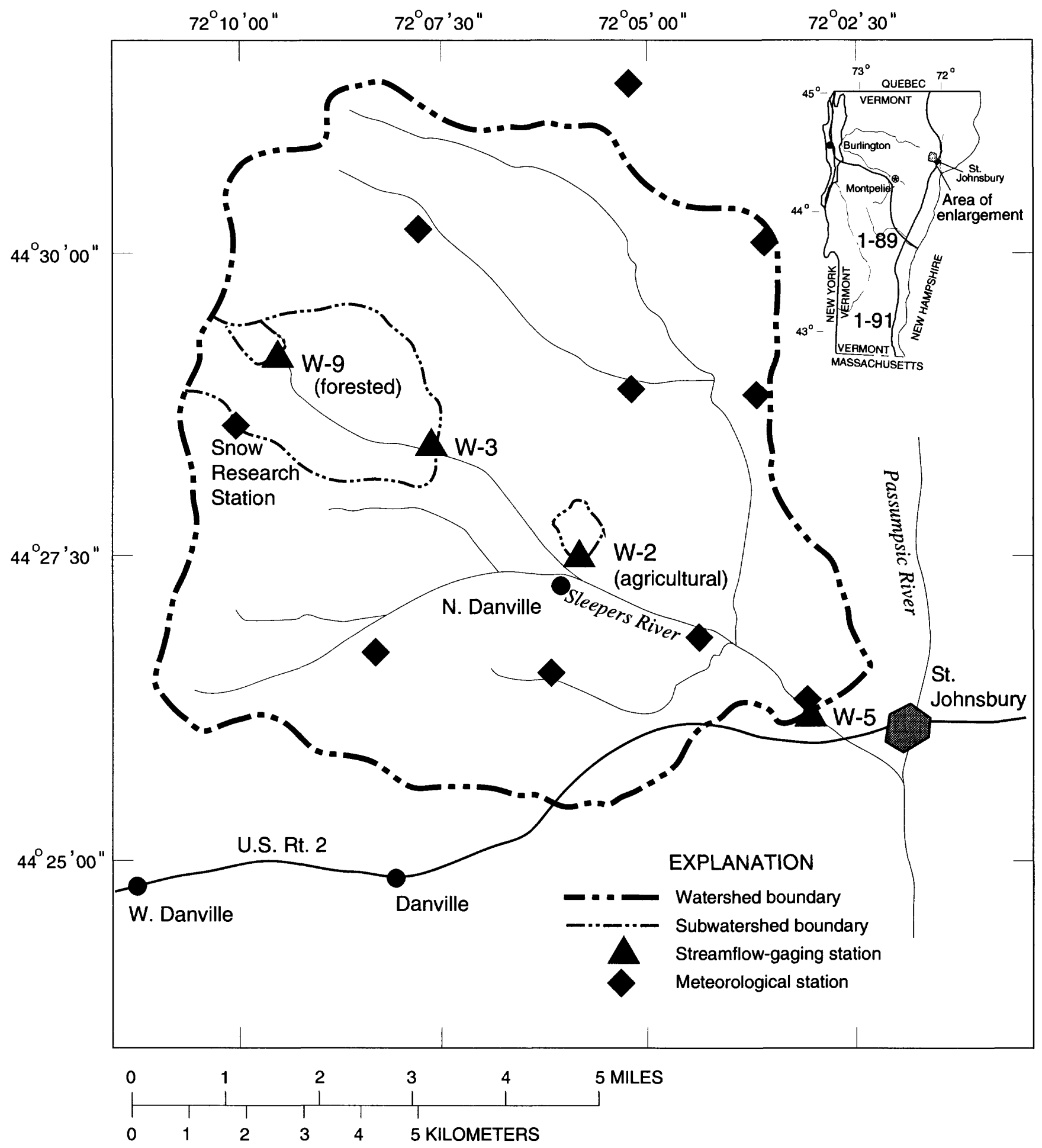

Figure 1. Location of streamflow-gaging stations and meteorological stations in Sleepers River Research Watershed, Vermont. 


\section{Historical Data-Collection and Research Activities}

Sleepers River has one of the longest historical data bases and continuous research programs for a coldregion area in the United States. Hydrologic and energy data have been collected continuously since 1958 (Pionke and others, 1986). The site has been administered by the Agricultural Research Service of the U.S. Department of Agriculture (1957-1975), the Office of Hydrology of the National Weather Service (1966-1986) and the U.S. Army Cold Regions Research and Engineering Laboratory (CRREL) (1979 to present). Numerous other institutions and agencies also have participated in research at Sleepers River. The Sleepers River data set was selected by the World Meteorological Organization (WMO) as one of six highquality data sets for its project on the Intercomparison of Models of Snowmelt Runoff. Prior to USGS involvement, water quality had not been a major focus at Sleepers River, although some investigations of stream chemistry were made (Hall, 1971; Kunkle, 1971; Pangburn, 1981; Thorne, 1985).

The history of streamflow and meteorological data collection at the Sleepers River Research Watershed is summarized in tables 1 and 2. Meteorological data have been collected at the Snow Research Station (fig. 1)

Table 1. Drainage areas and periods of discharge records for subwatersheds of the Sleepers River Research Watershed, Vermont

$\left[\mathrm{km}^{2}\right.$, square kilometer]

\begin{tabular}{lrl}
\hline $\begin{array}{c}\text { Subwater- } \\
\text { shed No. }\end{array}$ & $\begin{array}{r}\text { Drainage } \\
\text { area } \\
\left(\mathrm{km}^{2}\right)\end{array}$ & \multicolumn{1}{c}{ Period of record } \\
\hline W-1 & 43.15 & $1958-85$ \\
W-2 & .59 & $1958-78 ; 1991$-present \\
W-3 & 8.40 & 1959 -present \\
W-4 & 43.70 & $1959-85$ \\
W-5 & 11.60 & $1959-$ present \\
W-6 & .68 & $1960-75$ \\
W-7 & 21.90 & $1960-75$ \\
W-8 & 15.71 & $1960-79$ \\
W-9 & .47 & $1961-78 ; 1990$-present \\
W-10 & 16.39 & $1962-85$ \\
W-11 & 2.29 & $1963-75$ \\
W-12 & 2.03 & $1964-75$ \\
W-13 & 1.04 & $1964-75$ \\
W-14 & 3.72 & $1964-75$ \\
W-15 & 4.76 & $1964-75$ \\
W-16 & 2.99 & $1965-92$ \\
W-18 & .52 & $1968-78$ \\
\hline
\end{tabular}

Table 2. Summary of meteorological data available at Sleepers River Research Watershed, Vermont

[" $R$ " designation refers to the 30 meteorological stations distributed throughout the 17 subwatersheds (Pionke and others, 1986); W-3 is 1 of 17 subwatersheds]

\begin{tabular}{|c|c|c|}
\hline $\begin{array}{l}\text { Period of } \\
\text { record }\end{array}$ & Sites & $\begin{array}{c}\text { Types of } \\
\text { measurements }\end{array}$ \\
\hline $1958-79$ & $\begin{array}{l}\text { R1 through } \\
\text { R30 }\end{array}$ & $\begin{array}{l}\text { Precipitation } \\
\text { Snowdepth and water } \\
\text { equivalent } \\
\text { Air temperature } \\
\text { Relative humidity } \\
\text { Wind speed/direction } \\
\text { (discontinuous) } \\
\text { Soil moisture } \\
\text { (discontinuous) }\end{array}$ \\
\hline $\begin{array}{l}\text { 1979- } \\
\text { present }\end{array}$ & $\begin{array}{l}\text { R3, R7, R8 } \\
\text { R10, R11, } \\
\text { R17, R19, R21, } \\
\text { R23, R24 }\end{array}$ & $\begin{array}{l}\text { Precipitation } \\
\text { Snow depth and water } \\
\text { equivalent } \\
\text { Air temperature } \\
\text { Relative humidity }\end{array}$ \\
\hline $\begin{array}{l}\text { 1984- } \\
\text { present }\end{array}$ & $\begin{array}{l}31 \text { sites } \\
\text { within W-3 }\end{array}$ & $\begin{array}{l}\text { Frozen-ground depth } \\
\text { Snow depth and water } \\
\text { equivalent }\end{array}$ \\
\hline
\end{tabular}

since 1968. Data collected at this site, in addition to those listed in table 2 , include vapor pressure, incident and reflected solar radiation, incoming longwave radiation, soil temperature, snow-cover density, snow-cover temperature, snow-cover outflow, and snow-surface density and temperature. The site locations are shown in figure 1. In addition to these continuous long-term data sets, short-term data sets include, for example, suspended sediment and bedload, base-cation concentrations, WMO intercomparison of solid precipitation gages, and stream and streambed temperature. Basin characteristics provided in map format include soil classifications, surficial geology, land use, stream order, and topography.

\section{Current Data-Collection Activities}

The core hydrologic and meteorological datacollection activity at Sleepers River is summarized in table 3. Seventeen subbasins were gaged from the late 1950 's to the late 1970's (table 1), although only four (W-2, W-3, W-5, and W-9; fig. 1) are currently operative. The meteorological data are from an 
Table 3. Summary of measurements and instrumentation for Sleepers River Research Watershed, Vermont

[Use of brand, trade, or firm names is for identification only and does not imply endorsement by the U.S. Geological Survey. WEBB, Water, Energy, and Biogeochemical Budgets. CRREL, Cold Regions Research and Engineering Laboratory. $\mathrm{cm}^{3}$, cubic centimeter; $\mathrm{m}$, meter; $\mathrm{ft}$, foot; in., inch]

\begin{tabular}{|c|c|c|c|c|}
\hline $\begin{array}{c}\text { Type of } \\
\text { measurement }\end{array}$ & Instrumentation & $\begin{array}{l}\text { Period of } \\
\text { record }\end{array}$ & $\begin{array}{l}\text { Measure- } \\
\text { ment } \\
\text { frequency }\end{array}$ & $\begin{array}{l}\text { Number } \\
\text { of sites }\end{array}$ \\
\hline
\end{tabular}

\section{Pre-WEBB measurements}

Air temperature

Vapor pressure

Wind speed

Incident solar radiation

Reflected solar radiation

Precipitation

Soil temperature

Snow-cover depth

Snow-cover density

Snow-surface density

Snow-cover temperature

Snow-cover outflow

Stream temperature

Stream discharge

Stream discharge

Frozen ground depth
Platinum resistance element

Lithium chloride dewcell $1.0 \mathrm{~m}$ above snow

Three-cup anemometers, $1.0 \mathrm{~m}$ above snow

Eppley pyranometer

Eppley pyranometer

Shielded universal gage, $6 \mathrm{ft}$ above ground

Thermocouples, 3, 6, 12, 24, 36 in. in depth

Snow courses and snow stakes

Adirondack snow tube

500- $\mathrm{cm}^{3}$ CRREL tubes

Thermocouples attached to wooden stake

Two 10-foot diameter lysimeters

Grant Model 1200

Stevens A-35 stage recorder

Stevens A-35 stage recorder

Methylene-blue-dye frost tubes

$\begin{array}{clr}\text { 11/69-present } & \text { Hourly } & 13 \\ \text { 11/69-present } & \text { Hourly } & 13 \\ \text { 11/69-present } & \text { Hourly } & 3 \\ \text { 6/70-present } & \text { Hourly } & 2 \\ \text { 3/73-present } & \text { Hourly } & 2 \\ \text { 12/68 to } & \text { Hourly } & 15 \\ \text { present } & & \\ \text { 12/68-9/87 } & \text { Hourly } & 1 \\ \text { 12/68-present } & \text { Daily } & 1 \\ \text { 12/68-present } & \text { Weekly } & 14 \\ \text { 12/68-present } & \text { Weekly } & 1 \\ \text { 12/68-9/87 } & \text { Hourly } & 1 \\ \text { 12/68-present } & \text { Hourly } & 2 \\ \text { 1984-present } & \text { Half-hourly } & 3 \\ \text { 1959-1979 } & \text { Continuous } & 15 \\ \text { 1959-present } & \text { Continuous } & 3 \\ \text { 1984-present } & \text { Weekly } & 31\end{array}$

9/91-present Weekly 1

11/90-present 5-minute 7

4/91-present Weekly plus 7

3/92-present Weekly in 3 season

3/92-present

Daily in season

11/91-present Half-hourly 22

7/92-present Bimonthly plus 30 events

8/92-present Hourly to 7 weekly

6/91-present 5-minute

\section{3}

2

13

2

1
2 15 3 31

CR-10 datalogger with precision thermistors

Potentiometer/datalogger
Ground-water levels
Time-domain reflectometry (TDR)

Ground-water chemistry

Ground-water

temperature

Ground-water levels

\begin{abstract}
Potentiometer/datalogger
\end{abstract}


Table 3. Summary of measurements and instrumentation for Sleepers River Research Watershed, Vermont -Continued

\begin{tabular}{llccc}
\hline \multicolumn{1}{c}{$\begin{array}{c}\text { Type of } \\
\text { measurement }\end{array}$} & \multicolumn{1}{c}{ Instrumentation } & $\begin{array}{c}\text { Period of } \\
\text { record }\end{array}$ & $\begin{array}{c}\text { Measure- } \\
\text { ment } \\
\text { frequency }\end{array}$ & $\begin{array}{c}\text { Number } \\
\text { of sites }\end{array}$ \\
\hline Ground-water levels & Electric tape & $6 / 91$-present & $\begin{array}{c}\text { Biweekly plus } \\
\text { events }\end{array}$ & 80 \\
Soil water chemistry & Zero-tension lysimeter & 11/91-present & $\begin{array}{c}\text { Events } \\
\text { (incremental) }\end{array}$ & 8 \\
Soil temperature & $\begin{array}{l}\text { CR-10 datalogger with precision } \\
\text { thermistors }\end{array}$ & 11/91-present & 5-minute & 20 \\
Thermal conductivity & $\begin{array}{l}\text { Transient hot-wire thermistor } \\
\text { CR-10 datalogger with precision } \\
\text { Stream temperature }\end{array}$ & 9/92-present & Periodic & 20 \\
\hline
\end{tabular}

intensive data-collection program at the Snow Research Station (1968 to present) and at nine auxiliary meteorological stations (fig. 1).

A geographic information system (GIS) coverage will be created for the entire drainage basin. A pilot GIS coverage for subbasin W-3 includes topography, soils and soil attributes, surficial and bedrock geology, land use/land cover, ground-surface spectral images (which include SPOT and LANDSAT), elevation, and slope and aspect data.

\section{WATER, ENERGY, AND BIOGEOCHEMICAL BUDGETS RESEARCH ACTIVITIES AT SLEEPERS RIVER RESEARCH WATERSHED}

In the Sleepers River WEBB project, the USGS is primarily responsible for hydrological and biogeochemical process research, whereas CRREL is primarily responsible for energy transfer process research. Both agencies interact to solve the engineering problems of field instrumentation in a cold-region environment. Because the two agencies share common research objectives, participation in all aspects and phases of the research are shared, thus taking full advantage of the different but complementary strengths of the two organizations. For example, CRREL expertise in the measurement of soil moisture in subfreezing conditions (McKim and others, 1980) benefits the research element on hillslope hydrochemistry; the reliable soil-moisture data are combined with chemical and isotopic behavior of the soil water to calculate solute fluxes and postulate how water moves through soil; these hypotheses on flow path are directly tested with
CRREL's thermal measurements, which then link thermal transfers in the snowpack and upper soil zone to water movement; conceptual models of flow paths on the hillslope are independently applied to the basin scale through evaluation of isotopes and biogeochemical fluxes (USGS) and thermal inputs to higher-order streams (CRREL) to assess the effect of basin scale on the relative importance of hydrochemical processes. This shared research approach is designed to lead to improved understanding of WEBB processes in this northern forest region.

\section{Research Elements}

The WEBB project at Sleepers River consists of five integrated research elements: hillslope hydrochemistry, flow-path delineation, effect of seasonal freezing and snowpack on trace-gas fluxes in soils, hydrologic processes at different scales, and energy processes in a northern temperate climate. The following descriptions of each research element include information on investigators and collaborators, problem statements, objectives, hypotheses to be tested, and research approaches.

\section{I-Hillslope Hydrochemistry}

This research element is designed to improve the understanding of the mechanisms by which water and solutes move from hillslope to stream.

Investigators and Collaborators.-The principal investigator is James B. Shanley (USGS, Montpelier, Vt.). Collaborators are Darryl Calkins (CRREL, 
Hanover, N.H.); Peter Murdoch (USGS, Albany, N.Y.); Jon Denner (USGS, Montpelier, Vt.); and Ann Chalmers (USGS, Montpelier, Vt.).

Problem.--Recent interest in drainage basin biogeochemistry has led to a major research effort aimed at an improved understanding of streamflow-generation mechanisms. Field verification has not kept pace with the proliferation of new conceptual models of drainage basin hydrologic processes. Particularly beginning in the 1980 's, efforts have focused on the linkages between hydrological and biogeochemical processes. This interest (and the lack of understanding of the linkages) was highlighted by the convening of the Chapman Conference on Hydrogeochemical Responses of Forested Catchments in Bar Harbor, Maine, in September 1989 (American Geophysical Union, 1989). Researchers are confronted by a host of conflicting and confusing findings; isotopic tracers, for example, may lead to one set of conclusions about flow paths that generate streamflow, whereas conservative chemical tracers may lead to another (Hooper and Shoemaker, 1986). Thus, although the body of evidence now indicates that "old water"- that is, water present in the basin before the runoff-generating event-dominates the storm hydrograph (for example, Sklash and Farvolden, 1979; Pearce and others, 1986), hydrologists do not agree on the mechanism that produces this result.

Similar debates are ongoing about the mechanisms that control headwater-stream chemistry. In one approach, changes in streamwater chemistry are explained by variations in the mixture of water from different flow paths, each flow path characterized by a distinctive, invariant chemistry (Hooper and others, 1990). In more traditional conceptualizations, chemistry varies along specific flow paths with changes in residence time and hydrologic regime. One emerging hypothesis is that the riparian zone-the interface between the terrestrial and aquatic zones, and thus the part of the terrestrial ecosystem that water last contacts before entering the stream-has a major effect on streamwater chemistry (Bishop and Rodhe, 1989). The riparian zone has not, to date, been given the explicit attention that it may merit in relation to its importance in controlling stream chemistry.

Dunne and Black (1970a,b) collected water from a seepage face at the base of a hillslope at Sleepers River. They observed that the subsurface hydrologic response could account for only a very small part of the event hydrograph, and they used this observation to support their hypothesis that the stormflow hydrograph was dominated by direct inputs to the saturated partial contributing areas near the stream channel. Pangburn (1981), working on the steeper hillslopes toward the basin headwaters, attributed greater importance to subsurface flow. Such discrepancies are common in hydrologic flow-path studies. The question of how hydrologic inputs to a hillslope are routed to the stream is best addressed by measuring the temporal and spatial dynamics of soil-moisture and water-table fluctuations. Coupling these physical measurements with monitoring of the chemical and isotopic composition of soil and ground water offers the best possible opportunity for understanding the hydrochemical response of the hillslope.

Objectives.- To investigate and describe the linkages between soil hydrology and solute transport in the soil zone by detailed accounting of water and chemical fluxes at points on a hillslope, with special emphasis on the riparian zone.

Hypothesis 1: In Sleepers River soils, developed on carbonate-bearing till, the upper soil horizons have been leached of carbonate so that water traveling along shallow flow paths (for example, moving laterally along discontinuities in hydrologic conductivity) will acquire little alkalinity and remain distinct and readily identifiable from water traveling along deeper flow paths, which will be enriched in alkalinity from carbonate weathering.

Hypothesis 2: Subsurface flow in hillslopes makes a significant hydrological (and chemical) contribution to the event hydrograph, in excess of the amount produced from saturation-excess overland flow in near-stream partial contributing areas.

Hypothesis 3: The chemistry of water draining a hillslope to the stream channel is significantly modified by processes in the riparian zone.

Approach.-Hydrologic and chemical fluxes are being measured at an extensively instrumented hillslope in W-9, the forested headwater basin. The hillslope in W-9 was selected as a representative hillslope in terms of average slope, aspect, upslope contributing area, and till thickness. Till is generally thin at headwater sites (Newell, 1970), but the structure and hydraulic conductivity of the till are expected to control subsurface flow paths. Seismic refraction transects (Haeni, 1986) were applied to select a candidate 
hillslope; the selected hillslope has a till thickness of 2 to $3 \mathrm{~m}$, which is a typical thickness for the W-9 basin. A transect of three soil pits along the downslope gradient were excavated and intensively instrumented (fig. 2). A mid-slope shelter houses dataloggers and controls for the physical sampling and data acquisition. Future hillslope studies may be extended to W-2, the small agricultural basin.

During the excavation of the soil pits, a complete suite of soil samples were collected for determination of soil hydrologic properties including field capacity, moisture retention, and saturated and unsaturated hydraulic conductivity (Ingersoll, 1981). On the upslope face of each pit, lysimeters were installed at three depths, together with a complementary array of probes (at six depths) for time domain reflectometry (TDR) to determine soil-moisture content (see below). At each pit, one well was installed for water-quality sampling of ground water, and a second well was installed for continuous recording of ground-water level by means of a float and counterweight interfaced with a potentiometer. The temporal pattern of soil-moisture content will be analyzed to track the progress of wetting fronts down the soil profile. Downward flux of soil moisture will be related to water-table fluctuations observed in the recording wells. In the riparian zone at the base of the hillslope, nested piezometers and wells screened at

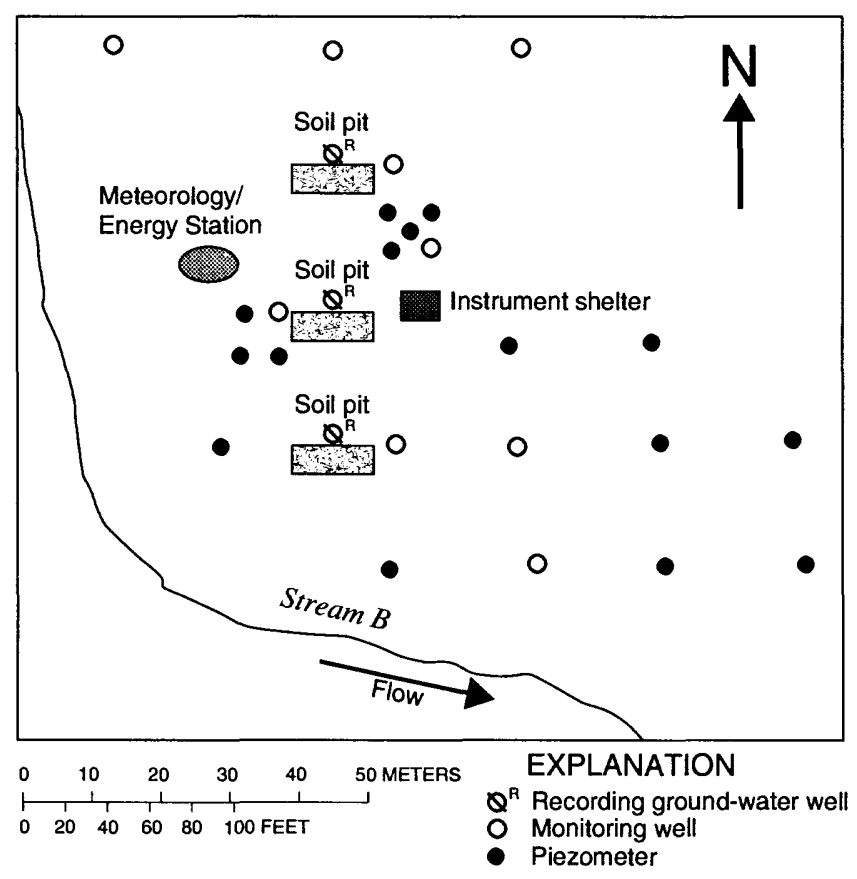

Figure 2. Hillslope hydrology research plot, Vermont. $60-\mathrm{cm}$ intervals have been installed to delineate hydraulic and chemical gradients within the saturated zone. Additional piezometers will be installed as necessary to determine the hydraulics in the riparian area, such as whether or not ground-water mounding occurs (Winter, 1988).

Collection of water samples for chemical analysis on the hillslope is event-based, with a sampling frequency on the order of several times per day. At least five hydrologic events are sampled per year, focused on periods of highest water flux (spring snowmelt, summer thunderstorms, and autumn rains). In anticipation that important changes in water quality will occur in the riparian zone, the sampling network is designed for increased sampling intensity toward the stream. Sampling will be carried out with sufficient frequency and spatial intensity so that the chemical responsechanges in $\mathrm{pH}$, specific conductance, and the concentrations of the major dissolved solutes $(\mathrm{Ca}, \mathrm{Mg}, \mathrm{Na}, \mathrm{K}$, $\mathrm{NH}_{4}, \mathrm{Cl}, \mathrm{NO}_{3}, \mathrm{SO}_{4}$, and alkalinity), silica, and dissolved organic carbon (DOC) - can be linked to the transient responses of soil moisture and ground water. These chemical and hydrologic variations and their linkages will form the basis for identifying and understanding the major hydrochemical processes on the hillslope.

Intensive sampling during storms or snowmelt includes sequential sampling of precipitation and throughfall (not yet implemented as of June 1994), soil water, shallow ground water, and streamwater. Sequential samples of precipitation and throughfall will be collected with automated wetfall/dryfall collectors modified with a funnel leading to a series of bottles designed to fill in sequence. Sequential snowmelt samples are collected from $1-\mathrm{m}^{2}$ plexiglass plates, and at a nearby site by use of a specially constructed snow lysimeter (Greenan and Anderson, 1984). Soil water is collected from zero-tension lysimeters of molded polyethylene pressed vertically upward against the horizontal ceiling of a cavity prepared in the uphill wall of each soil pit. Each lysimeter drains to a buried collection vessel from which the soil water is pumped to the surface. A method may be devised to record the timing of water delivery to the collection vessels (possibly by weighing bucket). The amount of water collected by the lysimeters is measured when water-quality samples are collected to provide a crude estimate of water flux in the unsaturated zone. These data are compared to changes in soil-water content as recorded by TDR. Water-quality samples from wells are collected as frequently as possible during storms and snowmelt. If ground-water 
chemistry changes rapidly, one well will be instrumented with an automatic water sampler to coincide with stream sampling at the base of the hillslope.

Physical properties such as water temperature and ground-frost depth are measured to augment the hydrologic and chemical data. Temperature probes have been installed in the stream and streambed, in several waterquality wells, and at all points where soil moisture is being measured. Stream temperature can be used to identify sources of water input to a stream (Shanley and Peters, 1988). Temperature likewise can be used to identify sources of ground-water recharge (Robert Newton, Smith College, personal commun., 1990), and it is currently used at Sleepers River to monitor inputs of snowmelt and ground water to large streams (Pangburn, 1987). Another important physical factor affecting hillslope hydrologic processes is the extent of ground frost and its depth of penetration. Ground-frost measurements using tubes of methylene blue dye have been made at a network of 31 points in a variety of aspect and cover types at Sleepers River since 1984. A technique based on resistivity (Atkins, 1979), which would allow for electronic logging of frost penetration, is currently being refined.

The hydrologic, chemical, and isotopic transfers from precipitation/snowmelt through the hillslope to the stream will establish the basis for identifying and understanding WEBB processes. A conceptualization of the dominant hillslope hydrochemical processes will be formulated from the detailed data on the hydrochemical response of the hillslope to hydrologic events. To evaluate this conceptualization and to test new hypotheses that may arise, tracer experiments are planned. Under a variety of antecedent conditions, lithium bromide will be applied to the hillslope plot prior to hydrologic events. The mass movement of the bromide will be closely tracked so that hydrologic pathways can be inferred; observed chemical changes will be interpreted in light of the amounts of "new" water-that is, water contributed directly from rain or snowmelt-that passes through that point. Bromide is an appropriate tracer because it is highly conservative and because it is present in only trace amounts in most terrestrial ecosystems. Although more expensive than other bromide salts, lithium bromide is preferred because lithium is not being measured as part of the routine water-quality analyses. The intent of these artificial tracer experiments is to verify the identification and understanding of the WEBB processes on the hillslope derived from the interpretation of the natural hydrochemical response.

\section{II-Flow-Path Delineation}

Several stable isotopes, including ${ }^{18} \mathrm{O},{ }^{2} \mathrm{H},{ }^{13} \mathrm{C}$, ${ }^{87} \mathrm{Sr} /{ }^{86} \mathrm{Sr}$, and isotopes of $\mathrm{Pb}$ will be used to determine the source of water and solutes in streamflow.

Investigators and Collaborators.-The principal investigator is Carol Kendall (USGS, Menlo Park, Calif.). Collaborators are Tom Bullen (USGS, Menlo Park, Calif.) and James B. Shanley (USGS, Montpelier, Vt.)

Problem.-Stable isotopic tracers are commonly used as a tool for investigating the processes regulating the variation of water solutes and their transport along hydrologic flow paths in catchments. Assuming short residence times and limited exchange with the vapor phase, stable isotopes of oxygen and hydrogen are recognized as conservative because they are an integral part of the water molecule. If the isotopic compositions of the various sources of water (for example, rainwater, ground water, and soil water) are known and are different, then the relative amounts contributing over time to streamflow quantity and quality can be determined.

Research at a number of watersheds has shown that the amount of water stored in the unsaturated zone is important in explaining stormflow quantity and quality (Kennedy and others, 1986; DeWalle and others, 1987). Although the isotopic compositions of rainwater and ground water are relatively easy to determine, the amount and isotopic compositions of soil water are difficult to evaluate because of the heterogeneity of flow paths in the unsaturated zone; among these difficulties is variability in the amount of water that moves through soil macropores as opposed to water that moves through the soil matrix. Variation in the isotopic composition of soil water is frequently substantial. At present, little is understood about the processes affecting the isotopic composition of water in the unsaturated zone; thus, what constitutes an adequate characterization of the soil water for use in hydrograph separations is unclear. Although soil waters can be sampled by various techniques (including cores, suction lysimeters, and pan lysimeters), researchers debate about whether these techniques collect samples that represent the water that is actually moving through the soil (DeWalle and others, 1987; Wenner and others, 1991).

Although the relative contributions of water from precipitation and ground water to streamflow can be determined using oxygen and hydrogen isotopic compositions, the contribution from soil water is difficult to quantify. At Sleepers River, ${ }^{13} \mathrm{C}$ is being 
tested as a potential tool to identify the soil-water contribution. Research at watersheds in Catoctin Mountain, Md. and Mill Run, Va. has shown that the carbon isotopic composition of water traveling along a particular flow path is isotopically labeled by the composition of the predominant source of dissolved inorganic carbon (DIC) in that water. Although there are many possible complicating factors, DIC is derived from one of three processes: (1) strong acid weathering of calcite (all $\mathrm{C}$ from $\mathrm{CaCO}_{3}, \delta^{13} \mathrm{C}=0$ permil), (2) carbonic acid weathering of silicates (all $\mathrm{C}$ from plantrespired $\mathrm{CO}_{2}, \delta^{13} \mathrm{C}=-22$ permil), or (3) carbonic acid weathering of calcite (one $C$ from each source, $\delta^{13}$ $\mathrm{C}=-11$ permil). Thus, subject to biogeochemical controls, soil water is likely to have a characteristic $\delta^{13} \mathrm{C}$.

At Catoctin and Mill Run, a relatively small amount of calcite is present in the shallow soil zone. Therefore, DIC in soil water traveling along shallow flow paths primarily is bicarbonate resulting from dissolution of silicates by carbonic acid, and hence its $\delta^{13} \mathrm{C}$ is similar to that of plant-respired carbon dioxide. These shallow waters are significantly depleted in ${ }^{13} \mathrm{C}$ compared to deeper ground waters where the DIC is derived from carbonic acid dissolution of calcite under closed conditions, or compared with waters that reflect the effect of strong acid dissolution of calcite along deep flow paths, such as bedrock fractures.

The carbon isotopic composition of stream DIC also reflects seasonal variations in hydrologic flow paths and sources of carbon. For example, at Catoctin, most of the DIC in the winter is derived from strongacid weathering of calcite, whereas during the growing season, the alkalinity results primarily from carbonic acid dissolution of calcite with minor silicate weathering. Thus, the carbon isotopes provide a measure of the relative amounts of silicate as opposed to calcite weathering reactions contributing to water chemistry. The combination of oxygen isotopes as tracers of rainwater and ground-water (and possibly soil-water) contributions to streamflow, plus carbon isotopes as indicators of deep or shallow flow paths, will improve the ability to quantify the contributions of water and solutes from different sources and flow paths as compared to the use of oxygen isotopes alone.

In large rivers, the exchange of DIC with atmospheric and biogenic carbon dioxide may prevent attempts to identify the original sources and relative amounts of terrestrial carbon by use of the $\delta^{13} \mathrm{C}$ of DIC (Mook, 1968; Hitchon and Krouse, 1972). Because of these problems, few studies of the $\delta^{13} \mathrm{C}$ of stream DIC have been done. In first-order streams, isotopic exchange is virtually absent, and the $\delta^{13} \mathrm{C}$ values are useful indicators of the seasonal and storm-related changes in carbon sources and water flow paths (Kendall and others, 1992). Along long stream reaches, isotopic exchange eventually will become significant, but how far downstream carbon isotopes will continue to be a useful label is not presently known.

All current studies in the USGS that use carbon isotopes to trace weathering reactions, carbon sources, and water flow paths in shallow systems are in crystalline or noncarbonate sedimentary rocks where calcite is present in only trace amounts. In carbonaterich environments like Sleepers River, carbon isotopes may be even more useful as tracers. On the premise that silicate weathering by carbonic acid is the dominant DIC-producing reaction in the carbonate-poor, organicrich upper soil zone, the depleted $\delta^{13} \mathrm{C}$ of the resultant DIC is expected to provide a useful label of waters following shallow flow paths. Waters from deeper in the system, where dissolution of calcite by soil-derived carbonic acid is a dominant source of alkalinity, would be markedly depleted in carbon isotopic composition relative to shallow soil water because of the two sources of carbon.

Objectives.-The main focus of this research element is the application of oxygen isotopes, carbon isotopes, and water chemistry to trace sources of water and solutes and changes in water flow path over time and space in the drainage basin.

Hypothesis 1: Because soils developed on the carbonate-bearing till have been partially leached of carbonate, waters traveling along shallow flow paths will have lower alkalinity and will be more enriched in ${ }^{13} \mathrm{C}$ than waters derived from deeper flow paths.

Hypothesis 2: The $\delta^{13} \mathrm{C}$ of DIC can be applied together with $\delta^{18} \mathrm{O}$ to improve the determination of changes in water flow path and weathering reactions caused by seasonal and event-related changes in the hydrologic regime. The $\delta^{13} \mathrm{C}$ of shallow waters shows less spatial, temporal, and storm-related variation than does the $\delta^{18} \mathrm{O}$; applied together, they may provide a more useful label of shallow waters than does $\delta^{18} \mathrm{O}$ alone.

Hypothesis 3: The $\delta^{13} \mathrm{C}$ of DIC in third- or higher-order streams maintains the characteristic isotopic signatures of the carbon 
sources and can be usefully analyzed to determine the approximate contributions of different sources and flow paths of water to large drainage basins.

Approach.- Variations of $\delta^{13} \mathrm{C}$ with depth are expected in Sleepers River soils. The $\delta^{13} \mathrm{C}$ of the shallow system will be controlled by the amount of calcite present, the relative rates of soil $\mathrm{CO}_{2}$ production and diffusion, and the amount of silicate weathering. Weathering of silicates by carbonic acid in carbonatepoor soils will produce DIC with a $\delta^{13} \mathrm{C}$ similar to soilderived $\mathrm{CO}_{2}$ (about -22 permil). If calcite is being dissolved by strong acids, the $\delta^{13} \mathrm{C}$ should be identical to that of the calcite (about -2 permil in rocks of the Waits River formation). Deeper in the system, calcite is present in greater quantities and it is weathered by carbonic-acid dissolution. Therefore, the $\delta^{13} \mathrm{C}$ of deeper ground water should be intermediate between calcite and carbonic acid (about -12 permil), assuming that exchange with soil $\mathrm{CO}_{2}$ is minimal.

To determine seasonal variation in sources and flow paths on the basis of oxygen and carbon isotopes, the investigators will collect monthly surface-water samples at the three streamflow gages for 2 years. To test the use of ${ }^{13} \mathrm{C}$ as a tracer of shallow flow paths, the investigators must quantify the variation of soil carbon dioxide with season, area, and depth. Soil gas is sampled by pumping from hollow pipes installed in the ground at various depths. Soil gas will be collected and analyzed for $\delta{ }^{13} \mathrm{C}$ bimonthly at sites colocated with the hillslope hydrochemistry sites and the soil-trace-gas measurement sites. Shallow ground water from the hillslope sites and regional ground water from deep wells near the basin outlet also will be sampled bimonthly for 2 years and analyzed for ${ }^{13} \mathrm{C}$. Baseline data from the bimonthly ground-water and soil-gas sampling will be compared to the more dynamic hydrologic event data.

Samples of bedrock and unweathered till were collected from 20 sites in the drainage basin in an attempt to account for spatial variations in composition. To confirm that there is no selective dissolution of one type of carbonate with a different carbon isotopic composition (unlikely, but not impossible), the investigators will analyze selected samples of carbonate from the soilweathering zone. Samples for ${ }^{13} \mathrm{C}$ must be filtered and fixed with ammoniated $\mathrm{SrCl}_{2}$ immediately after collection. After the $\mathrm{SrCO}_{3}$ precipitate is filtered, it can be stored indefinitely before analysis. Because of the relative ease of ${ }^{18} \mathrm{O}$ sampling and analysis compared to ${ }^{13} \mathrm{C}$, an ${ }^{18} \mathrm{O}$ sample will be collected as an aliquot drawn from each water-quality sample. Samples for $\delta^{18} \mathrm{O}$ analysis will be stockpiled and analyzed selectively on the basis of other features of the sample and (or) hydrologic event. A selected subset of samples will be analyzed for ${ }^{2} \mathrm{H}(\delta \mathrm{D})$ to test whether $\delta^{18} \mathrm{O}$ values have been affected by evaporation.

Effective use of carbon and oxygen isotopes for hydrograph separation requires the collection of sequential rain and (or) throughfall samples for $\delta^{18} \mathrm{O}$, stream samples distributed over the hydrograph for $\delta^{13} \mathrm{C}$ and $\delta^{18} \mathrm{O}$ (as many as 24 samples per storm), sequential soil-water samples during the storm (for $\delta^{13} \mathrm{C}$ and $\delta^{18} \mathrm{O}$ ), and prestorm samples of streamwater, ground water, and soil water. About 150 samples were collected for ${ }^{13} \mathrm{C}$ analysis as a pilot study during the 1993 snowmelt period. If successful, a minimum of three hydrologic events per year, including the main snowmelt event, will be sampled for $\delta^{13} \mathrm{C}$. Because the $\delta^{18} \mathrm{O}$ of event water (precipitation or snowmelt) is not always distinguishable from that of ground water, not all samples will be analyzed for ${ }^{18} \mathrm{O}$. Analysis of the $\delta^{18} \mathrm{O}$ of the precipitation or snowmelt (the hydrologic input) for a given event will indicate whether further isotopic analyses of samples from that storm are warranted.

Two additional elements used for isotopic analysis at Sleepers River are $\mathrm{Sr}$ and $\mathrm{Pb}$. Sr is relatively abundant at Sleepers River because the geochemical behavior of $\mathrm{Sr}$ is similar to that of $\mathrm{Ca}$, resulting in substitution of $\mathrm{Sr}$ for $\mathrm{Ca}$ in mineral structures. The Waits River Formation that underlies nearly all of the Sleepers River drainage basin is a metamorphosed marl that contains a carbonate-rich granulite interfingered with a more silicate-rich quartz-mica schist. Weathering of the silicate phase yields a higher (more radiogenic) ${ }^{87} \mathrm{Sr} /{ }^{86} \mathrm{Sr}$ than does weathering of the carbonate phase. As soil develops from till, the more readily weathered carbonates are preferentially removed. Thus, water moving through the shallow soil zone reflects weathering of the remaining silicate phase and tends to acquire a relatively radiogenic ${ }^{87} \mathrm{Sr} /{ }^{86} \mathrm{Sr}$. In this way, relative abundances of $\mathrm{Sr}$ isotopes are an indicator of hydrologic flow paths. Each small stream sampled at Sleepers River has a characteristic ${ }^{87} \mathrm{Sr} /{ }^{86} \mathrm{Sr}$, apparently reflecting differences in relative abundances of the two phases of the Waits River Formation in the parent rock and till.

The $\mathrm{Pb}$ isotope analyses have distinguished two distinct sources of $\mathrm{Pb}$ : atmospheric deposition and rock weathering. Streamwater $\mathrm{Pb}$ is a simple mixture of $\mathrm{Pb}$ from these two sources. Whereas $\mathrm{Pb}$ from rock 
weathering dominates $\mathrm{Pb}$ concentrations in streamwater during base flow, the isotopic signature of $\mathrm{Pb}$ in streamwater shifts towards that of atmospheric deposition during high-flow periods. Therefore, $\mathrm{Pb}$ isotopes provide an additional constraint for the interpretation of hydrologic flow paths and the identification of solute sources.

\section{III-Effects of Seasonal Freezing and Snowpack on Soil Trace-Gas Budgets}

Fluxes of greenhouse gases $\left(\mathrm{CO}_{2}, \mathrm{~N}_{2} \mathrm{O}\right.$, and $\left.\mathrm{CH}_{4}\right)$ from soil and snowpack will be measured to determine seasonal patterns and infer processes controlling the fluxes.

Investigators and Collaborators.-The principal investigator is Eric T. Sundquist (USGS, Woods Hole, Mass.). Collaborators are Gregory Winston (USGS, Woods Hole, Mass.) and Janet Hardy (CRREL, Hanover, N.H.).

Problem.-A primary motivation for globalchange research is societal concern about the enhancement of the greenhouse effect by trace-gas emissions. Although the atmospheric concentrations of several trace gases are known to be increasing rapidly, large and fundamental uncertainties remain in the global budgets of some of the most radiatively important trace gases. Recent assessments of the global budgets for $\mathrm{CO}_{2}, \mathrm{~N}_{2} \mathrm{O}$, and $\mathrm{CH}_{4}$ have emphasized that land-surface processes may contribute to significant budget imbalances in ways that are either unknown or poorly understood. A recent analysis of global data for atmospheric and oceanic $\mathrm{CO}_{2}$ concluded that "total $\mathrm{CO}_{2}$ uptake by the oceans is considerably less than uptake by terrestrial systems" (Tans and others, 1990). Terrestrial uptake of $\mathrm{CO}_{2}$ is thought to account for the "missing $\mathrm{CO}_{2}$ sink" in the global carbon budget (Dixon and others, 1994), but how this terrestrial uptake occurs is unclear. Likewise, recent oceanic measurements of $\mathrm{N}_{2} \mathrm{O}$ support the belief that the principal source of $\mathrm{N}_{2} \mathrm{O}$ is the land surface rather than the oceans. Many mechanisms linked to changes in land use have been proposed to explain the increase in atmospheric $\mathrm{CH}_{4}$, providing the global budget for this gas with a surfeit of possible sources and perhaps a dearth of possible sinks. All of these global-budget uncertainties point insistently toward the requirement for improved understanding of land-surface sources and sinks.
Soil disturbances by human activities likely account for much of the apparent imbalance in the present-day global $\mathrm{CO}_{2}, \mathrm{~N}_{2} \mathrm{O}$, and $\mathrm{CH}_{4}$ budgets. Although effects associated with tropical deforestation are well publicized, recent research also has emphasized the importance of human activities in northern temperate regions. Following are a few specific findings:

1. In their global $\mathrm{CO}_{2}$ analysis, Tans and others (1990) suggested that, to balance the global $\mathrm{CO}_{2}$ budget, "a large terrestrial $\left[\mathrm{CO}_{2}\right]$ sink at northern temperate latitudes is necessary." The hypothesis of a land $\mathrm{CO}_{2}$ sink is not new. Both reforestation and $\mathrm{CO}_{2}$ "fertilization" have long been suggested as $\mathrm{CO}_{2}$ sinks at temperate latitudes, and reforestation is particularly widespread throughout the northeastern United States. These processes store carbon in vegetation; thus, the fate of the harvested forest biomass becomes a central longterm question. Associated changes in soil carbon storage are potentially more significant. The importance of soil effects is reinforced by the observation that natural plant productivity is controlled primarily by the availability of nutrients and water in soils.

2. Microorganisms in aerobic soils constitute the largest biological sink of $\mathrm{CH}_{4}$, and recent studies suggest that temperate and boreal aerobic forest soils consume at least as much $\mathrm{CH}_{4}$ as that consumed by tropical soils (Stuedler and others, 1989). The consumption of $\mathrm{CH}_{4}$ in aerobic soils is diminished by conversion from forest to agricultural use (Keller and others, 1990).

3. $\mathrm{N}_{2} \mathrm{O}$ production, which occurs during nitrification and denitrification in soil, has been shown to increase as a result of clear cutting (Bowden and Bormann, 1986) and excess nitrogen deposition (Aber and others, 1989) in forests in the northeastern United States. Fields fertilized with nitrogen also release considerable $\mathrm{N}_{2} \mathrm{O}$ to the atmosphere (Bremner and Blackmer, 1978).

4. Several northern temperate regions are uniquely susceptible to large-scale biogeochemical disturbances associated with acid deposition. Sulfur and nitrogen emissions affect soil trace-gas budgets in ways that are only beginning to be understood. For example, acid deposition may diminish the amount of $\mathrm{CO}_{2}$ consumed in weathering reactions involving carbonic acid. Nitrogen deposition 
seems to enhance the production of $\mathrm{N}_{2} \mathrm{O}$ (Aber and others, 1989) and inhibit the uptake of $\mathrm{CH}_{4}$ (Stuedler and others, 1989) in aerobic soils.

Superimposed on these effects of changing land use and acid deposition, the effects of climate change may have a potentially large influence on future trace-gas budgets. Biogeochemical feedbacks to climate change are one of the principal uncertainties in predicting future atmospheric trace-gas concentrations. Because climate models consistently predict greater greenhouse warming at high latitudes than at low latitudes (Houghton and others, 1990), it is especially important to improve the understanding of such feedbacks in temperate and boreal regions.

One of the most sensitive and important types of potential feedbacks is the response of soil trace-gas fluxes to changes in seasonal freezing and snowpack. These feedbacks are inherently related not only to complex biogeochemical processes but also to intricate interactions with water and energy fluxes. Winter cooling and drying dramatically slow the microbiological processes that control soil trace-gas fluxes. Because seasonal cooling and drying are attenuated with increasing soil depth, the soil surface zone that is the most active in the warmer months becomes less active relative to the deeper soil horizons in the winter. At the same time, persistent snowpack limits exchange with the atmosphere, thereby enhancing soil retention of water, heat, and trace gases (Solomon and Cerling, 1987). Snow recrystallization and episodic melt/freeze cycles can induce the formation of impermeable frozen layers and zones of concentrated solutes (Bales and others, 1989).

The complex winter interactions are important not only for their direct control on winter trace-gas fluxes, but also because they determine the condition of the soils prior to spring snowmelt. In many temperate regions, the spring thaw is the most important annual event controlling water, energy, and biogeochemical budgets at the land surface. The rapid release of stored water is accompanied by large heat transfer to the soils. Biological activity near the soil surface increases dramatically, and snowmelt elution of concentrated ions may cause chemical interactions that cannot occur at any other time of the year.

It should be emphasized that the study of effects of seasonal freezing and snowpack on soil-trace gases is a very new area of research. Although the above hypotheses provide a basis for initial planning, unexpected results may necessitate revised directions of inquiry.
Objectives.-This study will explore the sensitivity of trace-gas budgets to the combined effects of changing land use, acid deposition, and climate in northern temperate regions, with particular emphasis on the role of processes associated with seasonal freezing and snowpack.

Hypothesis 1: Conversion of forest to agricultural land enhances the release of $\mathrm{CO}_{2}$ and $\mathrm{N}_{2} \mathrm{O}$ from soil and diminishes the uptake of $\mathrm{CH}_{4}$ by soil. Reforestation effects are opposite. The magnitude of these effects is affected by the soil response to seasonal freezing and snowpack accumulation.

Hypothesis 2: The relative sensitivities of soil microbial trace-gas fluxes to seasonal freezing and snowpack can be approximated as a function of soil depth. Microbial processes near the soil surface (for example, most of the $\mathrm{CO}_{2}$ production) will be most sensitive, whereas microbial processes deeper in the soil profile (such as production of $\mathrm{N}_{2} \mathrm{O}$ from denitrification) will be least sensitive.

Hypothesis 3: Soil production and consumption of $\mathrm{CO}_{2}, \mathrm{~N}_{2} \mathrm{O}$, and $\mathrm{CH}_{4}$ continue throughout the winter and must be included in annual trace-gas budgets. Concentrations of these trace gases in the soil and snow can be modeled reasonably as a one-dimensional balance among production, consumption, and vertical transport.

Hypothesis 4: The response of soil $\mathrm{CO}_{2}, \mathrm{~N}_{2} \mathrm{O}$, and $\mathrm{CH}_{4}$ fluxes to spring snowmelt is determined primarily by the effects of snowmelt on soil-moisture content and retention. Above-freezing temperature variations and elution of ions from accumulated acid deposition are secondary influences during snowmelt.

Approach.-The hypotheses will be examined by a combination of field and laboratory experiments. The initial emphasis is on laboratory studies to design and test sampling equipment, to estimate expected soil trace-gas production and consumption rates, and to assess one-dimensional transport models. These studies will serve as a guide for the design of field experiments.

Because this study emphasizes the importance of variations in trace-gas processes as a function of soil depth (see particularly hypothesis 2 ), it is critical to establish soil-gas monitoring procedures that provide a detailed record of significant depth-dependent 
variations. Although procedures for sampling and analyzing soil solutions and solids have received much attention, procedures for measuring concentrations and fluxes of soil gases are relatively undeveloped and unstandardized. In particular, methods developed for sampling gases in the deep unsaturated zone (greater than $0.5 \mathrm{~m}$ below land surface) are not appropriate for sampling the uppermost part of the soil profile, where spatial and temporal variations in microbial turnover are greatest and where accurate determination of timedependent vertical gradients is most critical to modeling exchange with the atmosphere.

This sampling problem will be studied under closely controlled laboratory conditions. $\mathrm{A} \mathrm{CO}_{2}$ "flux generator" will be assembled using a $\mathrm{pH}$-stat with two autoburettes configured to titrate additions of carbonate or bicarbonate with acid. Gas equilibrated with the titration solution will be exposed to columns filled with various inert (sterile) unsaturated soil materials representative of the study area. The $\mathrm{pH}$-stat arrangement will allow precise control of the $\mathrm{CO}_{2}$ concentration at the source and of either constant or variable $\mathrm{CO}_{2}$ fluxes. $\mathrm{CO}_{2}$ concentration gradients will be measured in samples obtained from the columns by use of various active and passive sampling techniques. $\mathrm{CO}_{2}$ fluxes will be monitored with a nondispersive infrared analyzer. These experiments should help to establish the reliability of various sampling techniques and should provide an excellent opportunity to evaluate the adequacy of one-dimensional soil-gas-transport models under both steady-state and non-steady-state conditions (hypothesis 3).

Analogous experiments will be run on columns of snow, cold and frozen soil, and snow over unsterilized soil in cold room facilities at CRREL. Effects of melting and freezing will be simulated by inducing temperature changes in some column experiments. Care will be taken to recognize disturbance effects from soilsample collection. These studies will benefit from interaction with ongoing and proposed CRREL studies of the behavior of reactive trace species in snow and ice. Studies of reactive species (such as sulfur dioxide, ozone, formaldehyde, and hydrogen peroxide) naturally complement work done in this study on gases that are relatively unreactive in snow and ice. Similarly, research in this study on soil interactions also complements CRREL research with ice cores, where the records of reactive and unreactive species are not affected by underlying soils.
Another series of laboratory experiments will be a sequence of soil incubations to study the effects of variations in temperature, moisture content, and amendments representative of rainfall and meltwater elution. Data on $\mathrm{CO}_{2}, \mathrm{~N}_{2} \mathrm{O}$, and $\mathrm{CH}_{4}$ production and consumption in these experiments will be the principal basis for testing hypothesis 4. Data from experiments on samples from various soil horizons will contribute to testing hypothesis 2 .

Field measurements require close collaboration with the site coordinator and other investigators to take full advantage of the opportunity to coordinate trace-gas measurements with measurements of water, energy, and other biogeochemical fluxes. Gas-sampling tubes, designed on the basis of the sampling experiments described above, have been deployed with the soiltemperature and -moisture sensors in the intensive hillslope study site (research element I). During the winter, gas-sampling tubes will be mounted on dowels above ground for snowpack sampling at the same sites.

Concentrations and fluxes of $\mathrm{CO}_{2}$ are monitored throughout the year in both soils and snow (hypotheses 2 and 3). Future monitoring will extend to $\mathrm{N}_{2} \mathrm{O}$ and $\mathrm{CH}_{4}$. The frequency of field sampling has varied from monthly to quarterly. Several 24- and 48-hour experiments have been performed to monitor diurnal cycles in concentrations and fluxes of $\mathrm{CO}_{2}$ at different times of year. If possible, sampling will be automated with a pocket-calculator-controlled valve system already developed in a separate project. In addition to the gas sampling tubes installed with sensors for other studies, special procedures (to be developed in the sampling experiments) will be applied for high-resolution sampling of extreme concentration gradients just below the soil surface (partial pressures of $\mathrm{CO}_{2}$ in the soil may be 100 times those in the atmosphere). Concentrations are determined within a few hours of sampling by gas chromatography either at the field site or in a nearby building, and fluxes are measured by determining timedependent concentration changes in chambers placed on the soil surface. In the case of $\mathrm{CO}_{2}$, fluxes are measured in situ with a nondispersive infrared analyzer. To ensure comparability with measurements in these smallvolume profiles, $\mathrm{CO}_{2}$ concentrations will be determined in the large-volume soil gas samples collected for ${ }^{13} \mathrm{C}$ analysis.

Data needs for the above studies are met almost entirely on the basis of available project facilities. Gas concentrations are measured by gas chromatography with flame ionization detection for $\mathrm{CH}_{4}$ and $\mathrm{CO}_{2}$ (after methanization) and electron capture detection for $\mathrm{N}_{2} \mathrm{O}$. 
These methods are capable of analyzing the very small samples (a few milliliters) necessary for detailed study of gradients near the soil surface. In addition, $\mathrm{CO}_{2}$ and water-vapor fluxes are measured by a nondispersive infrared analyzer originally designed for field measurement of photosynthesis. Additional data needs will be for measurement of dissolved nitrogen (including $\mathrm{N}_{2} \mathrm{O}$ ) and carbon species in soil water and for characterization of bulk chemical and physical properties of soil and snow.

\section{IV-Hydrologic Processes at Different Scales}

The dominant streamflow-generation mechanisms at the small drainage basin scale will be evaluated for their relevance in progressively larger basins; new mechanisms will be postulated and investigated as appropriate.

Investigators and Collaborators.-The principal investigator is David Wolock (USGS, Lawrence, Kans.). Collaborators are James B. Shanley (USGS, Montpelier, Vt.) and Thor Smith (University of New Hampshire, Durham, N.H.)

Problem.-During hydrologic events, the hillslope supplies water to the near-stream riparian areas where the saturated area expands (Dunne and Black, 1970b). Runoff to the channel occurs as a result of direct inputs to the saturated area (rainfall and snowmelt directly on the area, or snowmelt reaching the area by runoff over frozen ground) or by continued supply from the hillslope. The mechanisms that cause water delivery to a stream channel from a hillslope may differ from one basin to another as a function of topography, depth to bedrock (or an impermeable layer), and hydraulic conductivity. These factors are believed to control differences among hillslopes in the amount of water that contributes to event flow relative to the amount that contributes to base flow from slower subsurface seepage. It is not known, however, how these physical factors vary with basin size.

The relative amounts of streamflow arising from subsurface and surface flow paths vary over space and time. In some basins, the chemical and isotopic signatures of streamflow indicate that the water comes predominantly from deep subsurface flow paths; in other basins, the data indicate a greater importance of surface runoff. As basin scale increases, these factors are expected to change such that shifts occur in the dominant source of water to the stream. The hydrologic processes important to streamflow generation at the plot or hillslope level become blurred by differences in hydrologic routing. Processes that may be absent in first-order basins, such as regional ground-water discharge, may become important in larger basins.

In a basin with substantial relief such as Sleepers River, nearly all water appearing as channel flow originated as rainfall or snowmelt input to a hillslope. The hillslope hydrochemistry research (element I) is designed to identify the mechanisms by which water is delivered from the hillslope surface to the stream channel. Key to scaling up from this two-dimensional picture to the three-dimensional problem of understanding the hydrologic response of a basin is the linkage between hillslope-flow processes and the dynamics of the saturated partial contributing areas adjacent to the channels. An understanding of the linkage between local hillslope flow and regional ground-water flow also is important.

Objectives.-The objectives of this research element are twofold: (1) to determine the partitioning of hydrologic pathways as basin scale increases, and (2) to determine if differences in dominant flow paths for basins of different size can be explained by differences in physical factors.

Hypothesis 1: As basin size increases, the topography becomes flatter and the percentage of convergent areas increases; average depth to bedrock increases; and average hydraulic conductivity increases.

Hypothesis 2: As basin size increases, flatter topography leads to a greater areal extent of saturated contributing areas, promoting surface runoff, whereas increases in depth-tobedrock and hydraulic conductivity tend to promote subsurface runoff. The effect of increases in depth-to-bedrock and hydraulic conductivity outweighs the effect of flatter topography; thus, the proportion of surface runoff decreases as basin size increases.

Approach.-To investigate the linkage between hillslope-flow processes and the dynamics of the saturated partial contributing areas adjacent to the channels thought to be important in the hydrologic response of larger basins (Dunne and Black, 1970b), the investigators will monitor the dynamics of these contributing areas in the field. The objective is to assess whether the flow-path partitioning based on chemical and isotopic data is consistent with expansion and contraction of 
these areas, and to assess whether changes in flow-path partitioning with increasing basin scale can be explained in terms of physical factors in the basin.

To test the first hypothesis, USGS digital elevation data was acquired. Algorithms developed at the USGS office in West Trenton, N.J. were applied to the nested basins to calculate parameters that quantify flatness and percentage of convergent areas. These topographic parameters and their effect on flow paths are described in Wolock and others (1990). Soil-survey data will be used to estimate average depth-to-bedrock according to methods described in Wolock and others (1989). Average hydraulic conductivity for the nested basins is available from slug-test data.

The chemical and isotopic flow-path information from research elements I and II will indicate the fraction of surface runoff in the streamflow for each of the nested basins, and that information will be evaluated to test the second hypothesis. The extent of riparian saturated zones in each basin will be monitored by field observation and mapping, supplemented in some areas by grids of surface-saturation sensors triggered by lateral entry of water at ground level. The relations between the flowpath data and the physical factors will be used to test the validity of TOPMODEL, a topographically based hydrologic model (Beven and Kirkby, 1979). Sensitivity analyses of the model will be run to determine if the simulated relations between flow path and physical factors are consistent with observations.

TOPMODEL will be calibrated to data collected at the three nested basins and the agricultural basin using the digital topography from the USGS Digital Elevation Model. A chemical component may be coupled to TOPMODEL (Wolock and others, 1990) to test whether processes identified as important in controlling the concentrations of certain constituents are consistent with the flow regimes predicted by the model. The SSSAR model (U.S. Army Engineer Division, 1972), which has already been calibrated to W-3 and W-5, may provide additional confirmation for the flow-path partitioning. The grid of surface-saturation sensors, installed along the maximum possible extent of the partial contributing areas, will provide ground-truth verification of saturated contributing areas simulated by TOPMODEL during high-runoff events.

The relative similarity of bedrock and till materials underlying Sleepers River drainage basin simplifies the task of relating hydrologic controls to changes in physical characteristics; for example, because till is derived from the local bedrock, which is uniform, differences in hydraulic conductivity can be related to variations in till texture. Additional evaluation of the role of physical factors in determining flow paths will be gained by applying TOPMODEL to several other subbasins, where historical flow and chemistry data also are available (Pangburn, 1981) for further evaluation of the effect of basin size on hydrologic flow path.

\section{$\mathrm{V}$-Energy Processes in a Northern Temperate Climate}

Energy-flux measurements will be used to prepare a detailed energy balance at a point; the processes that integrate energy fluxes at the watershed scale will be investigated to extrapolate the point balance to a three-dimensional model.

Investigators and Collaborators.-The principal investigator is Mary Albert (CRREL, Hanover, N.H.). Collaborators are Darryl Calkins (CRREL, Hanover, N.H.); Timothy Pangburn (CRREL, Hanover, N.H.); Janet Hardy (CRREL, Hanover, N.H.); Robert Davis (CRREL, Hanover, N.H.); Sam Colbeck (CRREL, Hanover, N.H.); and James B. Shanley (USGS, Montpelier, Vt.)

Problem.-Energy fluxes must be considered to adequately simulate the long-term effects of climate on the hydrologic system. The role of basinwide energy processes and thermal regimes in the context of drainage-basin runoff response has either been overlooked or avoided in previous investigations, owing to the perceived complexity of the problem. Factors such as slope, aspect, vegetation, soil type, and moisture content all play a role in determining heat fluxes and the subsequent temperature profiles; how these factors should be integrated into the drainage-basin runoff response (quantity and quality) is unclear. Energydriven processes have been incorporated into parts of the hydrologic response, namely in calculations and estimates of evapotranspiration. A contribution of watershed-runoff response from the combined mass and energy fluxes has not been thoroughly researched nor incorporated into available runoff-simulation models.

Attempts to develop a process-level understanding of the role of energy fluxes in the drainage-basin-runoff response are problematic for two reasons; the processes are not completely understood at a point, and current distributed models do not incorporate knowledge of pointbased processes. Existing point-energy-budget models of snowmelt do not account for many process-level phenomena (Anderson, 1978; Leavesley, 1989; Marsh, 
1990). Determination of the effects of climatic forcing on snow distribution and snowmelt runoff requires an improved understanding of the following processes:

1. variation of net radiation caused by different canopy densities and types,

2. infiltration into frozen soil or partially frozen soil,

3. development and decay of ice layers in the snow or at the ground surface,

4. hydraulic properties of wet snow during metamorphosis,

5. turbulent energy transfer over irregular terrain where vegetation and snow surface are variable,

6. snow/soil heat and vapor flux, and

7. rain-on-snow processes.

The limitations to the understanding of these processes have reduced the application of point-based energy process models in a distributed framework to drainage-basin-scale systems. Available distributed snowmelt models only account for horizontal-plane variations in snowmelt and snow distribution (Morris, 1985). Distributed energy-input models for the snowpack have been developed (Dozier, 1980; Sambles and others, 1990); however, they characterize the effects of vegetation by means of empirical relations. Further, the coupled effects of ground frost and its spatial variations have not been addressed.

Objectives.-The objectives of this research element are threefold. The first objective is to characterize the thermal regimes and to determine the distribution and magnitude of the basin heat fluxes in representative vegetation and terrain settings in the drainage basin. This characterization will be done for various time scales in order to understand the episodic, seasonal, and annual responses of thermal regimes to changes in the incoming surface energy and geothermal fluxes. The second objective is to determine the distribution, magnitude, and variability of the snow/soil thermal and water-flux regimes at the plot scale during runoff events (summer and winter). The final objective is to determine if the temporal change in the thermal regime of the soils (temperature, thermal conductivity or diffusivity) measured by in situ sensors can be used as an indicator for hydrologic flow paths during snowmelt and summer runoff events.
Hypothesis 1: The characterization of the drainage-basin thermal regime (soil and water) can be established from energy-flux measurements at several point locations and from detailed plot studies.

Hypothesis 2: Thermal properties of soil (temperature, soil moisture, soil thermal conductivity/diffusivity) can be used to identify hydrologic flow paths at the plot scale that can be translated to the basin scale.

Hypothesis 3: A change in the incoming-solarenergy flux to a drainage basin is reflected in its hydrologic response.

Approach.-Understanding the effects of the thermal regime on the hydrologic response of the basin requires both field research and modeling. The field data provide the spatial and temporal ranges in variables in the basin, as well as calibration and validation to models simulating the mass and energy exchanges at small scales or points. This information is essential to making the link between the point and drainage-basin scales. Historically, CRREL has investigated many energycontrolled processes for cold-region environments (such as soil freeze/thaw processes and water and vapor transport in soil and snow). However, these analyses have not been applied at drainage-basin scales. In addition to the basic research of the WEBB project, the energy-budget data will serve the other WEBB research elements as well as provide a basis to test other ongoing CRRELfunded research on integrated physically-based modular modeling systems for gaining an understanding of process interactions at the watershed scale.

Temperature and heat flux data-collection activities will provide information on the heat transport within and from the basin. The Snow Research Station (fig. 1) is the primary data-collection site because of the historical record of measurements at that site (1968 to present). Temperatures of the surface and subsurface waters, heatflux rates, and heat storage are being measured; the heat transport to the ground-water system is considered as an integration of sources in the unsaturated zone and geothermal heat. Twelve additional sites have been selected for measurements of energy-flux profiles. Sites were chosen on the basis of terrain elements controlling the surface-energy exchange: slope, aspect, vegetation, canopy, and soil type. Geothermal and in-ground heat fluxes will be measured at the sites by use of commercial flux meters. Detailed energy and water budgets will be prepared at the hillslope site (research element I) and at several other of the energy-flux sites. 
At the 12 energy-flux sites, soil temperature and thermal conductivity/diffusivity are sampled at high spatial and temporal resolution. The other types of data collected at these sites are soil moisture, incoming and outgoing energy fluxes, precipitation, and air temperature. Effort is focused at the plot scale, where the variability and reliability of the measurements can be best understood. At the remaining (control) sites, short-term experiments will be run to document the range in thermal conditions for the different geographic areas and vegetative groups in the basin.

To determine the limitations of point energybudget models and to show the relative dominance of processes under various climatic conditions, the investigators will evaluate the 26 years of energy-budget data at the Snow Research Station. Anderson (1978) used this data set to develop the most widely applied pointenergy and mass-balance model of a snow cover. To couple the modular thermal models with a runoff model applicable to drainage-basin-scale processes for snowcovered and non-snow-covered conditions, the investigators will take the following steps.

1. Analyze the relations between long-term heat transfer and storage at the Snow Research Station and the long-term climatic record. Compare the snow/soil characteristics in a magnitude-frequency context with extreme, shortduration events or episodes to identify the driving energy- and mass-flux relations that control runoff processes.

2. Test physically based modules for integrating thermal processes into runoff models at the point, plot, and drainage-basin scales. The development of coupled runoff and thermal modules is perceived to follow multiple directions at this time. An initial approach will assess the seasonal heat and mass storage in the soil/water system in relation to the seasonal heat transport at different basin scales to determine if any patterns or correlations are readily seen for yearly time scales. A second approach takes advantage of the short-term dynamics of the system; during short time periods of high input of water flux or energy flux (for example, a rain-onsnow event), changes in the near soil/snow temperature conditions may correspond to runoff conditions within the upper soil zone. Available heattransport models for conduction with phase change are available to simulate the thermal response of soils to changes in incoming energy and moisture conditions. These models or modifications thereof will be used as tools to investigate heat and mass transport in the upper soil horizons. A third approach will be the development of an analytical solution to coupling of a heat transport model to the runoff model that incorporates non-snow- and snowmelt-runoff events. A calibrated and tested model of the thermal state and hydrologic response for the Sleepers River Basin will provide a tool to explore processes at small and large scales in time and space.

\section{Supporting Laboratory Facilities}

Conductance and $\mathrm{pH}$ are determined on all samples at the USGS laboratory in Montpelier, Vt. Major chemical constituents are analyzed at either the USGS laboratory in Albany, N.Y., or the CRREL laboratory in Hanover, N.H. Alkalinity, silica, dissolved organic carbon, and ammonium are determined at the Albany laboratory. Analysis of major cations (calcium, magnesium, sodium, and potassium) and major anions (sulfate, nitrate, and chloride) are divided between the laboratories on the basis of ionic strength: low-ionic-strength samples are analyzed at Albany and high-ionic-strength samples at CRREL. At both laboratories, cations are analyzed by flame atomic absorption spectrophotometry and anions by ion chromotography.

Isotope samples are analyzed by Carol Kendall and Tom Bullen at the USGS stable isotope lab in Menlo Park, Calif. Trace-gas analyses are run by Eric Sundquist and Greg Winston by gas chromatography either on site or at CRREL.

\section{Other Research Activities}

The University of Vermont (UVM) has ongoing research and data-collection activity at Sleepers River. UVM collaborates with CRREL on field-data collection and data processing and is in the process of compiling all historic data in a single data base. E. Alan Cassell of UVM interacts with USGS and CRREL researchers on hydrologic investigations for the WEBB project; prior to the WEBB study he developed an object-oriented hydrologic model for Sleepers River. UVM also has created a GIS data base for the W-3 subbasin.

An intersite comparison is in progress between Sleepers River subbasin W-9 (the forested headwater site) and two drainage basins about $100 \mathrm{~km}$ southsouthwest of Sleepers River in New Hampshire. These are Hubbard Brook Watershed 3, which has a 25-year hydrologic and water-quality data base, and Cone Pond Watershed, which was instrumented in the early 1980's. The three basins represent a spectrum of acidneutralizing capacities (ANC) from Cone Pond 
(chronically acidic) to Hubbard Brook (low ANC) to Sleepers River (high ANC). The intersite comparison is based on weekly collections of precipitation and streamwater at each site. The objective is to compare input/output budgets at the three basins for 3 years, and then to expand the comparison to biogeochemical processes. Sleepers River WEBB personnel also interact with researchers at the USGS research site at Mirror Lake, N.H., adjacent to the Hubbard Brook drainage basins.

Sleepers River WEBB personnel interact extensively with other USGS researchers in the New York District (Peter Murdoch, Greg Lawrence, Douglas Burns) as common members of the USGS Watershed Research Group of New York and New England (WARP-NYNE). These collaborations have centered on field assistance and information exchanges among USGS drainage basin projects at Sleepers River, the Catskill Mountains, N.Y., Cone Pond, N.H., and a regional spruce/fir aluminum chemistry study. The group also works collectively to augment and expand current projects and to design new projects, and it shares and supports a common analytical laboratory at the USGS New York District office.

Dartmouth College researchers (Ken Belitz, Bill Thomas) have investigated ground-water hydrology in subbasin W-9. They have applied the USGS modular ground-water model MODFLOW to simulate groundwater hydrology in the basin. Several wells and piezometers were installed to obtain input data for the model. Slug tests were performed on several wells to determine hydraulic conductivity. The distribution of glacial till thickness was determined during the well installations. MODFLOW was run to simulate the ground-water yield of the till. The simulated ground-water yield was much less than base-flow discharge at W-9, indicating that preferential flow paths within the till or within bedrock fractures are supplying base flow.

Thor Smith and Larry Dingman of the University of New Hampshire (UNH) are assisting in the hydrologic scale research element through a concerted field campaign. Anticipating that regional ground-water flow systems will contribute more water to streamflow as basin scale increases, UNH has installed wells in the larger basins to investigate ground-water hydrology and geochemistry in those systems. In addition, they have sampled seeps and streams throughout the basin in areas of varied land use in an attempt to identify "signal" water types, such as agricultural runoff, or deep regional ground-water flow, that mix in various proportions to form streamwater. The objective is to use the pattern of chemical and isotopic variations of streamwater, in conjunction with the known composition of the end members, to evaluate the changing nature of hydrologic flow paths as basin scale increases.

Amy Titus and Jeffrey McDonnell of the State University of New York at Syracuse (SUNY-Syracuse) are investigating the dynamics of saturated area development around stream channels in subbasin W-9, the forested headwater catchment. The project entails field reconnaissance and mapping to delineate saturated areas over a range of hydrologic conditions, and extensive sampling of streamwater, surface-saturated-soil water, and unsaturated-zone-soil water near the channel. All samples will be analyzed for ${ }^{18} \mathrm{O}$, and a subset will be analyzed for major-solute chemistry in order to determine the mechanisms by which the saturated areas are generated and sustained, and to determine the origin of the water that flows to the stream within the saturated areas. Lithium bromide tracer tests will be run to monitor travel time and flow paths within the saturated areas. Infrared imagery from low-altitude flights is an additional tool being tested as an alternative technique for mapping saturated areas.

Researchers at the University of Bristol, England (principal: Malcolm Anderson) are currently conducting two research projects at the study area. In cooperation with CRREL, they are doing research on energy-balance modeling and the resultant snowpack distribution. They are also leading geomorphologic and slope stability studies at Sleepers River.

Tom Siccama of Yale University, New Haven, Conn., and Jim Thorne of The Nature Conservancy, Philadelphia, Pa., have permanent forest transects and plots in the forested headwater basin at Sleepers River for quantitative inventory as part of their Ecological Data Exchange (EDEX) program. Three biomass inventories have been completed at approximately 6-year intervals. Also, Sleepers River is one of five test sites studied by researchers from Yale for their Peatland Hydrologic Impact Model.

Informal collaboration has been established with Dave Franzi at the State University of New York at Plattsburgh (SUNY-Plattsburgh) regarding aspects of glacial geology and soil geomorphology at Sleepers River. Student projects have been proposed to determine soil chemical properties at Sleepers River, using laboratory facilities at SUNY-Plattsburgh. 
Personnel from the Minnesota office of the Agricultural Research Service are calibrating the Agricultural Non-Point Source Pollution Model (AGNPS) in subbasin W-3. Transport of sediment, nitrogen, and phosphorus is simulated in the model.

The Connecticut River Basin is one of the basins selected in the initial phase of the USGS National Water Quality Assessment (NAWQA) Program. The Sleepers River drainage basin lies within the Connecticut River Basin, and it contains both forested and agricultural areas that are broadly representative of the basin. Thus, the main outlet gage (W-5) has been selected as a NAWQA indicator site. W-5 is being sampled monthly by NAWQA staff for complete chemical analysis, including pesticides. In addition, NAWQA staff periodically conduct biological surveys of stream fauna and analysis of fish tissues. The Sleepers River WEBB staff will cooperate with NAWQA personnel to interpret data from this sampling effort.

NAWQA-WEBB collaboration promises to be mutually beneficial. WEBB research will benefit the NAWQA program by providing process-oriented interpretation of seasonal and long-term trends in water quality at a scale corresponding to NAWQA indicator sites, and by providing a methodology to extend analysis of chemical concentrations and fluxes to much larger basin scales. NAWQA data can benefit WEBB research because the numerous NAWQA indicator sites constitute, in a sense, paired drainage basin comparisons to help isolate the effects of geology, topography, land use, and climate in the interpretation of data from WEBB sites. Linking these programs can combine detailed small-scale-process research with an understanding of how the effects of different processes may change at larger scales. This combination can provide a robust methodology for simulating future water-quality trends. Moreover, it is an excellent example of the process-to-system linkages that are crucial to understanding a wide variety of environmental problems.

\section{REFERENCES CITED}

Aber, J.D., Nadelhoffer, K.J., Stuedler, P., and Melillo, J.M., 1989, Nitrogen saturation in northern forest ecosystems: BioScience, v. 39, p. 378-386.

American Geophysical Union, 1989, Chapman Conference on Hydrogeochemical Responses of Forested Catchments, Bar Harbor, Proceedings, September 18-21, 1989.

Anderson, E.A., 1978, Streamflow simulation models for use on snow covered watersheds, in Modeling of Snow Cover Runoff, Hanover, N.H., Proceedings, September 26-28, 1978.
Atkins, R.T., 1979, Determination of frost penetration by soil resistivity measurements: Hanover, N.H., U.S. Army Cold Regions Research and Engineering Laboratory, Special Report 79-22, 24 p.

Bales, R.C., Davis, R.E., and Stanley, D.A., 1989, Ion elution through shallow homogeneous snow: Water Resources Research, v. 25, no. 8, p. 1869-1877.

Beven, K. and Kirkby, M.J., 1979, A physically based, variable contributing area model of basin hydrology: Hydrological Sciences Journal, v. 24, p. 43-69.

Bishop, K., and Rodhe, A., 1989, Tracing the origins of runoff in a hillslope with observations of hydraulic potential and stable isotope chemistry [abs.], in Chapman Conference on Hydrogeochemical Responses of Forested Catchments, Bar Harbor, Proceedings, September 18-21, 1989.

Bowden, W.B., and Bormann, F.H., 1986, Transport and loss of nitrous oxide in soil water after forest clear-cutting: Science, v. 233, p. 867-869.

Bremner, J.M., and Blackmer, A.M., 1978, Nitrous oxideemission from soils during nitrification of fertilizer nitrogen: Science, v. 199, p. 295-296.

DeWalle, D.R., Swistock, B.R. and Sharpe, W.E., 1987, Threecomponent tracer model for stormflow on a small Appalachian forested catchment: Journal of Hydrology, v. 104, p. 301-310.

Dixon, R.K., Brown, S., Houghton, R.A., Solomon, A.M., Trexler, M.C., and Wisniewski, J., 1994, Carbon pools and flux of global forest ecosystems: Science, v. 262, p. 185-190.

Dozier, Jeff, 1980, A clear-sky spectral solar radiation model for snow covered mountainous terrain: Water Resources Research, v. 16, no. 4, p. 709-718.

Dunne, Thomas, and Black, R.D., 1970a, An experimental investigation of runoff production in permeable soils: Water Resources Research, v. 6, no. 2, p. 478-490.

$1970 \mathrm{~b}$, Partial area contributions to storm runoff in a small New England watershed: Water Resources Research, v. 6, no. 5, p. 1296-1311.

1971, Runoff processes during snowmelt: Water Resources Research, v. 7, no. 5, p. 1160-1172.

Greenan, H.J., and Anderson, E.A., 1984, A snowmelt lysimeter for research applications: Annual Eastern Snow Conference, 41st Annual Meeting, Washington, D.C., June 78, 1984, Proceedings, p. 209-218.

Haeni, F.P., 1986, Application of seismic refraction methods in ground-water modeling studies in New England: Geophysics, v. 51, p. 236-249.

Hall, F.R., 1971, Dissolved solids-discharge relationships, 2, Applications to field data: Water Resources Research, v. 7, no. 3, p. 591-601.

Hitchon, B., and Krouse, H.R., 1972, Hydrogeochemistry of the surface waters of the MacKenzie River drainage basin, Canada-III. Stable isotopes of oxygen, carbon, and sulphur: Geochimica et Cosmochimica Acta, v. 36, p. 1337-1357.

Hooper, R.P., Christopherson, N., and Peters, N.E., 1990, Modeling streamwater chemistry as a mixture of soil water end members-an application to the Panola Mountain Watershed, Georgia, USA: Journal of Hydrology, v. 116, p. 321-343.

Hooper, R.P., and Shoemaker, C.A., 1986, A comparison of chemical and isotopic hydrograph separation: Water Resources Research, v. 22, no. 10, p. 1444-1454. 
Houghton, J.T., Jenkins, G.J., and Ephraums, J.J., (eds.), 1990, Climate change-The IPCC Scientific Assessment: Cambridge, Mass., Cambridge University Press, 365 p.

Ingersoll, J., 1981, Method for coincidentally determining soil hydraulic conductivity and moisture retention characteristics: Hanover, N.H., U.S. Army Cold Regions Research and Engineering Laboratory, CRREL Special Report 81-2.

Keller, M., Mitre, M.E., and Stallard, R.F., 1990, Consumption of atmospheric methane in soils of central Panama: effects of agricultural development: Global Biogeochemical Cycles, v. 4, p. 21-27.

Kendall, Carol, Mast, M.A., and Rice, K.C., 1992, Tracing watershed weathering reactions with $\delta^{13} \mathrm{C}$ in Kharaka, Y.K., and Maest, A.S., (eds.), Water-rock interaction, Balkema, Rotterdam, p. 569-572.

Kennedy, V.C., Kendall, C., Zellweger, G.W., Wyerman, T.A. and Avanzino, R.J., 1986, Determination of the components of stormflow using water chemistry and environmental isotopes, Mattole River Basin, California: Journal of Hydrology, v. 84, p. 107-140.

Kunkle, S.H., 1971, Effects of road salt on a Vermont stream: Journal of the American Water Works Association, v. 64, p. 290-295.

Leavesley, G.H., 1989, Problems of snowmelt runoff modeling for a variety of physiographic and climatic conditions: Hydrological Sciences Journal, v. 34, p. 617-634.

Marsh, P., 1990, Snow Hydrology, in Prowse, J.D., and Ommanney, C.S.L., (eds.), Northern HydrologyCanadian Perspectives: Saskatoon, Saskatchewan, NHRI Science Report No. 1.

McKim, H.L.,Walsh, J.E., and Arion, D.N., 1980, Review of techniques for measuring soil moisture in situ, Hanover, N.H., U.S. Army Cold Regions Research and Engineering Laboratory, Special Report 80-31, 17 p.

Mitchell, J.F.B. and Warrilow, D.A., 1987, Summer dryness in northern mid-latitudes due to increased $\mathrm{CO}_{2}$ : Science, v. 330 , p. $238-240$.

Mook, W.G., 1968, Geochemistry of the stable carbon and oxygen isotopes of natural waters in the Netherlands: University of Groningen, Netherlands, Ph.D. thesis, $160 \mathrm{p}$.

Morris, E.M., 1985, Snow and Ice, in Anderson, M.G., and Burt, T.P., (eds.), Hydrologic Forecasting: New York, John Wiley \& Sons.

Newell, W.L., 1970, Surficial geology of the Passumpsic Valley, northeastern Vermont: Baltimore, Md., Johns Hopkins University, Ph.D. thesis, University Microfilm 71-16743, $104 \mathrm{p}$.

Pangburn, T., 1987, Forecasting of snowmelt runoff using temperature data: Annual Eastern Snow Conference, 44th Annual Meetng, Fredericton, N.B., June 3-4, 1987, Proceedings, p. 108-113.

1981, Development of a water quality simulation model and its application to the Sleepers River Research Watershed: Hanover, N.H., Dartmouth College, M.S. thesis, $143 \mathrm{p}$.

Pearce, A.J., Stewart, M.K., and Sklash, M.G., 1986, Storm runoff generation in humid headwater catchments, 1 , where does the water come from?: Water Resources Research, v. 22, no. 8, p. 1263-1272.
Pionke, H.B., Chamberlin, B.J., McClure, P.L., Bahleda, K., and Kepes, J.C., 1986, Data directory, data and data collection site characteristics for the Sleepers River Watershed, N. Danville, Vermont: University Park, Pa., U.S. Department of Agriculture, Agricultural Research Service, Final Report.

Sambles, K.M., Pangburn, T., Harrison, A., and Anderson, M.G., 1990, A physically based model for the prediction of the spatial distribution of snowcover: Annual Eastern Snow Conference, 47th Annual Meeting, Bangor, Maine, June 5-7, 1990, Proceedings.

Shanley, J.B., and Peters, N.E., 1988, Preliminary observations of streamflow generation during storms in a forested Piedmont watershed using temperature as a tracer: Journal of Contaminant Hydrology, v. 3, p. 349-365.

Sklash, M.G., and Farvolden, R.N., 1979, The role of groundwater in storm runoff: Journal of Hydrology, v. 43, p. 45-65.

Solomon, D.K., and Cerling, T.E., 1987, The annual carbon dioxide cycle in a montane soil: observations, modeling, and implications for weathering: Water Resources Research, v. 23, no. 12, p. 2257-2265.

Stuedler, P.A., Bowden, R.D., Melillo, J.M., and Aber, J.D., 1989, Influence of nitrogen fertilization on methane uptake in temperate forest soils: Nature, v. 341, p. 314-316.

Tans, P.P., Fung, I.Y., and Takahashi, T., 1990, Observational constraints on the global atmospheric $\mathrm{CO}_{2}$ budget: Science, v. 247, p. 1431-1438.

Thorne, J.F., 1985, Nitrogen cycling in a base-poor and a relatively base-rich northern hardwood forest ecosystem: New Haven, Conn., Yale University, Ph.D. thesis.

U.S. Army Engineer Division, 1972, Program description and users manual for the Streamflow Synthesis and Reservoir Regulation (SSARR) Model: Portland, Oreg., U.S. Army Engineer Division, N. Pacific.

Wenner, D.B., Ketcham, P.D. and Dowd, J.F., 1991, Stable isotopic composition of waters in a small piedmont watershed, in Taylor H.P., O,Neil, J.R., and Kaplan, I.R., (eds.), Stable isotope geochemistry-A tribute to Samuel Epstein: The Geochemical Society, Special Publication No. 3, p. 195-203.

Winter, T.C., 1988, A conceptual framework for assessing cumulative impacts on the hydrology of nontidal wetlands: Environmental Management, v. 12, p. 605-620.

Wolock, D.M., Hornberger, G.M., Beven, K.J., and Campbell, W.G., 1989, The relationship of catchment topography and soil hydraulic characteristics to lake alkalinity in the northeastern United States: Water Resources Research, v. 25 , no. 5 , p. $829-837$.

Wolock, D.M., Hornberger, G.M., and Musgrove, T.J., 1990, Topographic effects on flow path and surface water chemistry of the Llyn Brianne catchments in Wales: Journal of Hydrology, v. 115, p. 243-259. 